\title{
Studying the outdoor performance of Organic Building-Integrated Photovoltaics laminated to the cladding of a building prototype
} Kettle, Jeffrey

\section{Solar Energy Materials and Solar Cells}

\author{
Published: 01/03/2019 \\ Peer reviewed version \\ Cyswllt i'r cyhoeddiad / Link to publication
}

Dyfyniad o'r fersiwn a gyhoeddwyd / Citation for published version (APA):

Kettle, J. (2019). Studying the outdoor performance of Organic Building-Integrated Photovoltaics laminated to the cladding of a building prototype. Solar Energy Materials and Solar Cells.

\footnotetext{
Hawliau Cyffredinol / General rights

Copyright and moral rights for the publications made accessible in the public portal are retained by the authors and/or other copyright owners and it is a condition of accessing publications that users recognise and abide by the legal requirements associated with these rights.

- Users may download and print one copy of any publication from the public portal for the purpose of private study or research.

- You may not further distribute the material or use it for any profit-making activity or commercial gain

- You may freely distribute the URL identifying the publication in the public portal ?
}

Take down policy

If you believe that this document breaches copyright please contact us providing details, and we will remove access to the work immediately and investigate your claim. 


\title{
Studying the outdoor performance of Organic Building-Integrated Photovoltaics laminated to the cladding of a building prototype
}

\author{
V. Stoichkov ${ }^{1}$, T.K.N. Sweet ${ }^{2}$, N. Jenkins ${ }^{2}$, J. Kettle ${ }^{1 *}$, \\ ${ }^{1}$ School of Electronic Engineering, Bangor University, Dean St, Gwynedd, Bangor, LL57 1UT, Wales, \\ UK. *E-mail: j.kettle@bangor.ac.uk \\ ${ }^{2}$ School of Engineering, Cardiff University, Queen's Buildings, The Parade, Cardiff, CF24 3AA, Wales, \\ UK
}

\section{Abstract}

The outdoor dependence of module orientation and diurnal climatic conditions on the performance of Organic Photovoltaics (OPVs) configured for Building Integrated PV (BIPV) arrays is reported. The study focuses upon a Northern European climate and the significance of module orientation upon energy yield across diurnal, seasonal change and climatic conditions are discussed. It is shown that the optimum position of a BIPV facade depends upon season and that a south facing BIPV facade provides the greatest energy yield during winter months. The results also show how west-facing modules can significantly contribute to power generation during peak power periods (5-8pm), which is imperative for balancing energy demand for buildings of the future and in particular supply the energy needs of buildings during peak hours in Northern Europe. Electrical characteristics under standard and part-load conditions were collated from laboratory scale OPV module experimental data and scaled for commercial-size modules in order to simulate BIPV arrays based upon OPVs. The simulated data is compared to experimental data and the closeness shows that BIPV systems based upon OPVs can be accurately simulated prior to installation. The system simulations compare typical energy demand profiles of small commercial buildings and illustrate that OPV arrays show strong potential to be used with excess energy generation for 8 months of the year based upon a $4.22 \mathrm{kWp}$ OPV system. Four 4.22kWp OPV systems scenarios have been investigated for (1) the highest annual energy generation, (2) architecturally evenly-spaced around the building (avoiding a North façade), (3) grid-balancing and (4) East-West split. Whilst Scenario 4 shows the lowest overall energy yield over the course of the year, energy production during peak hours is substantially higher than in other scenarios. The options presented show that OPVs are viable to use in BIPVs and can adequately meet the energy demand of a small commercial building during spring, summer and autumn in Norther Europe and can be adapted to end user's needs.

\section{Introduction}

Organic photovoltaics (OPV) has attracted substantial interest as a candidate for next generation photovoltaic devices due to its flexibility, semi-transparency, high speed manufacturing and low 
energy cost of production[1,2,3]. Whilst the benefits of the technology are clear, studying their operation in the real world under a variety of atmospheric conditions is vital in order to evaluate the technical potential of the technology[4,5]. Commercial OPV modules have been available to endusers for a number of years and demonstrators have been deployed in greenhouses, iPad chargers, bus shelter roofing and solar window applications $[6,7]$.

Building-integrated PVs (BIPVs) potential to seamlessly integrate into the building envelope holds aesthetic appeal for architects, builders, and property owners and is a market sector that is expected to grow dramatically over the next 5-10 years. Through the application of BIPVs, parts of a building's exterior can transform the building into being (at least partially) self-powering. In addition to cost constraints, BIPV technologies could provide a comparatively small amount of output power as the mounting of the module is determined by the building architecture and not necessarily at the optimal incidence angle. OPVs have the potential to be used in BIPV due to many of the advantages listed previously[6],[8]'[9], but there is a paucity of information in regards to the potential energy yield when OPVs are used for BIPVs and how energy yield changes as a function of diurnal and yearly solar and climatic conditions. In actual fact, there have been relatively few reports related to outdoor performance monitoring of OPVs, when compared to indoor tests, but markedly the reports conducted show that stability and internal architecture has a major impact for energy generation in outdoor enviroments[4,5], [10, 1112]. Recently, Angmo showed that OPVs could exist for up to 2 years with only $80 \%$ drop in its maximum output power[13]. Other promising reports include those by Hauch et al., reported the use of Polyethylene terephthalate (PET) as top barrier film in order to encapsulate Poly(3-hexylthiophene-2,5-diyl):Phenyl-C61-butyric acid methyl ester (P3HT:PCBM) flexible modules which suffered only $20 \%$ drop in performance over 12 months of outdoor exposure[11].

Within the European Union (EU), directive 2010/31/EU[14] states that all buildings occupied by public authorities built after 31st December 2018 should be nearly zero energy rated. The 2010/31/EU directive also states that all other new buildings must be nearly zero rated by 31st December 2020. This means that new buildings must generate their own energy from renewable sources and not be wholly reliant on traditional grid-based forms of fossil fuel related energy beyond these dates. Utilising the building infrastructure to host PV based generation via BIPV has the potential to provide an important component of this transition and enable organisations to comply with 2010/31/EU. From the early stages of OPV development, the potential for BIPV has been identified, owing to the lightweight, aesthetic properties and semi-transparency[15,16]. Companies such as Konarka argued that BIPV could be installed within north facing facades or vertical faces where c-Si modules would provide relatively poor performance. There are a number of companies 
globally trying to commercialise OPVs in building integrated applications. Arguably, the most advanced is Heliatek (Germany), who in November 2017 installed the world's largest building integrated organic photovoltaic' (BIOPV) system on top of a school in La Rochelle, France $(22 \mathrm{kWp})[17]$. Other demonstrators from Heliatek are based upon OPVs laminated onto windows, steel cladding as well as concrete. OPVius (Germany) (formerly Belectric) have also pursued BIPVs and also have a number of deployed systems. The highest profile are the 'OPV trees' which were demonstrated at the EXPO 2015 in Milan [8]. They also installed the first grid connected OPV systems $(0.2 \mathrm{kWp})$, which was based upon a sun sail attached to a building in Frankfurt in 2012 [18]. In 2017, they installed polycarbonate laminated OPV modules for roofing in France. Although these companies remain the most advanced in BIPVs, it is clear other businesses such as Polysolar (UK), InfinityPV (Denmark) have also developed or developing products in this space.

The development of the BIPVs attracted academic interest as well; most work in this area has focused upon semi-transparent [19,20], or even almost fully transparent devices [21]. After optimisation, efficiency can match that of a solar cell with an opaque electrode. A number of groups have investigated the application of OPVs onto opaque substrates such as steel [22-24], as this is a substrate often used in warehouses, roof cladding and also vehicles (i.e. for Vehicle Integrated PVs). The main challenge for a fully integrated BIPVs appears to be depositing a transparent top electrode as the underlying organic layers can easily be damaged by high temperatures or plasma deposition processes), but after identification of a suitable manufacturing route, the performance can match solar cells made on traditional glass or plastic substrates. Steel has the added benefit of being impermeable to water and oxygen, thus can protect the organic active layers from photo oxidation or water- driven degradation affects. Finally, another a growing interest has emerged to integrate OPVs with ETFE (ethylene tetrafluoroethylene) panels $[25,26]$ or other 3-dimensional building facades [5], where OPVs can follow contours in the substrate form owing to its flexibility. The last two references, in the context of this paper, show the importance of outdoor performance monitoring to accurately assess energy yield from different orientations and to inform of new degradation mechanisms that are unpredictable or difficult to notice from indoor testing, such as mechanical loading and delamination.

With growing interest in the use of OPVs in BIPV arrays, understanding of energy yield as a function of irradiance levels and seasonal variations is vital for users of the technology to assess the potential yield of arrays and optimise ways to utilise the technology. In this work, the outdoor performance of OPV modules with modules orientated on different sides of a building are monitored for their diurnal performance and energy yield with the view to providing information that could inform BIPV manufacturers. The results also show how the performance of differing module 
orientations is affected by seasonal variation and climatic conditions. Our results show the benefit of west-facing modules which can significantly contribute to balance the energy demand during peak hours in Northern Europe. The measured OPV module characteristics were extracted and systemlevel simulations were performed on a $4.22 \mathrm{kWp}$ system mounted onto a typical small commercial building (e.g. office operating weekdays, 08:00-18:00) with top, South, East, West and North-facing orientations to show the potential for BIPV integration of OPVs. The simulation shows that a BIPV system based on OPVs can supply daily energy demand for a small commercial building during spring, summer and autumn when irradiance (horizontal plane) exceeds $25 \mathrm{kWh} / \mathrm{m}^{2}$ with additional grid feed-in during this time surplus energy produced.

\section{Experimental procedure}

\subsection{Module encapsulation}

For this experiment, Roll-to-Roll (R2R) manufactured OPVs were acquired from InfinityPV Aps in Denmark. All modules were initially tested indoors using a Newport class A standard AM1.5G solar simulator, to ensure that all modules showed consistent performance prior to outdoor testing. These modules possessed a Power Conversion Efficiency (PCE) of around 3\% +/- $0.1 \%$ when measured under 1 Sun (AM1.5G) irradiation. All modules were bonded to the centre of a $205 \mathrm{~mm} x$ $160 \mathrm{~mm}$ silicon dioxide backplane. The encapsulation process consists of applying a thin layer of PolyDiMethylSiloxane (PDMS) onto the surface of the module to provide adhesion for a PolyEthylene Naphthalate $[27,28]$ (PEN) barrier film (supplied by DuPont Teijin in the UK) to be fixed over the top surface of the module. The PDMS is then allowed to cure in indoor ambient temperature without applying thermal/UV curing. The final stage of the encapsulation is concluded by sealing the edges of the modules with low temperature two-part fast curing sealing epoxy supplied by Greatcell Solar UK.

\subsection{Outdoor setup}

The outdoor experiments were performed for a period of 8 months, Dec 2015 - July 2016 at the School of Electronics, Bangor, Gwynedd, North Wales at coordinates latitude 53.23N, longitude 4.13W and altitude approximately $20 \mathrm{~m}$ above sea level. Long term climatic average temperatures for the winter are $4.7^{\circ} \mathrm{C}$ and for the summer are $14^{\circ} \mathrm{C}$. The humidity levels for both summer and winter were very similar: with an average mean of $79 \%$. UV indices were very different with an average of 1.07 in the summer (average maximum 5.45 ) and 0.43 in the winter (average maximum 2.38).

Performance Monitoring was conducted using an Egnitec PVMS250 PV measurement system (manufacturer Egnitec Ltd., Caernarfon, Gwynedd, UK). The modules are kept at maximum power point in between periodic current-voltage (IV) sweeps (once every minute) and each has a PT100 temperature sensor fixed to its backplane. Both the current and voltage data at the maximum power 
point ( $\left.\mathrm{I}_{\mathrm{MPP}}, \mathrm{V}_{\mathrm{MPP}}\right)$ and PT100 measurements were taken every 15 seconds. For these tests, a bespoke mount was manufactured so that two OPV modules could be mounted on each of the 5 faces of a cuboid structure, as shown in figure 1(a), so that modules were directed due South, North, East, West and top/horizontal at $0^{\circ}$ inclination.

During the outdoor testing, the incident irradiance was monitored using IMT silicon solar reference cells. The weather conditions were recorded every 1 minute using a Davis Pro weather station. There are two PT100 channels available for temperature monitoring of which one was used for reading the temperature accumulated by one of the two installed top-facing OPV modules. The outdoor measurement setup conforms to the ISOS-O-2 outdoor measuring protocol [13]. The data were analysed using a combination of MySQL, MS Access, and MS Excel. In order to study the degradation, OPV modules were removed from the outdoor test setup every 2 weeks and taken in to the laboratory where they were characterised for their performance under AM1.5G irradiance using a calibrated solar simulator

\subsection{Analysis of data}

The recorded OPV data was processed prior to data analysis. To calculate the Maximum power point, equation 1 was used, where $P$ is maximum generated power, $I_{m p p}$ is the current at maximum power point and $V_{\text {mpp }}$ is the voltage at maximum power point. Subsequently, the efficiency $\left(\eta_{S T C}\right)$ was calculated under Standard Test Conditions (STC) of $25^{\circ} \mathrm{C}$ and $1000 \mathrm{~W} / \mathrm{m}^{2} \mathrm{AM} 1.5 \mathrm{G}$ spectrum, as shown in equation 2, where $A$ is module active area $\left(\mathrm{m}^{2}\right)$ and $P_{\text {in }}$ is the solar irradiance $\left(\mathrm{W} / \mathrm{m}^{2}\right)$. Finally, energy yield $(Y)$ and energy Yield per unit area $(Y / A)$ was calculated based upon the measurement time interval $(t i)$.

$$
\begin{aligned}
& P=I_{m p p} * V_{m p p} \\
& \eta_{S T C}=\frac{P \max }{A * P i n} \\
& \mathrm{Y}=\int P d t \cong \sum i P i \Delta t i \\
& \frac{Y}{A}=\int P d t / A \cong \sum i P i \Delta t i / A
\end{aligned}
$$

\subsection{System-level simulations}

In order to simulate a BIPV system with OPV modules, climate data was created for Bangor (Latitude $53.23^{\circ}$ and Longitude $4.13^{\circ}$ ) using MeteoSyn climate data, averaged from 1991 to 2010 . The annual sum of global irradiation averages $1054 \mathrm{kWh} / \mathrm{m}^{2}$ with an annual average temperature of $10.6^{\circ} \mathrm{C}$. The electrical characterisation data from an OPV module measured outdoors in Bangor was collated under irradiance conditions of $950 \mathrm{~W} / \mathrm{m}^{2}$ and $299 \mathrm{~W} / \mathrm{m}^{2}$. This data was scaled for input to the 
simulation software under standard test conditions $\left(1000 \mathrm{~W} / \mathrm{m}^{2}\right)$ and under part-load conditions $\left(300 \mathrm{~W} / \mathrm{m}^{2}\right)$. In order to create the OPV module in the simulation software with valid user-defined data, the laboratory module $\left(0.0064 \mathrm{~m}^{2}\right.$ active area) electrical characterisation data was scaled to create a full-size module. The commercial-scale module comprised 100 laboratory modules, connected in parallel $\left(0.64 \mathrm{~m}^{2}\right.$ area). The current and Voltage data, within threshold values, was then input for complete systems-level simulations. Parallel connectivity of modules is preferred to series connection when there is a high probability of partial shading on a large-scale PV array. The experimental and simulation parameters are presented in Table 1.

The system was configured with a Sunny Boy 4000US, 4kW maximum AC power inverter. The 4 strings of 100 modules was connected in series with an active area of $256 \mathrm{~m}^{2}$ (i.e a $16 \times 16 \mathrm{~m}$ array) which has a peak power generating capacity of $4.22 \mathrm{kWp}$. Total cable losses were estimated as $2 \%$ in the models. The current at STC was designed to lie between 9.0 and $18.0 \mathrm{~A}$ (typically 12.4A). The sizing factor (SF) (equation 5) between 82 and 122\%. These values are dependent upon climate data and azimuth/inclination angles. PV modules operate for a large proportion of their time below their nominal rated power (under STC). Additionally, inverters spend significant proportions of time operating at power levels below the nominal array rating. By inverter under-sizing (taking the SF above $100 \%$ ) it is possible to take the normal operating regime higher up the inverter efficiency curve and therefore reduce losses at times of normal irradiance levels. Systems with inverters smaller than the array will, on occasions of high irradiance, have output clipped. The inverter will not be able to deliver all the available power to the grid, which may ultimately increase inverter lifetime.

The maximum power point voltage $\left(\mathrm{V}_{\mathrm{mpp}}\right)$ was specified to lie between 250 and $480 \mathrm{~V}$ (minimum $\mathrm{V}_{\mathrm{mpp}}$ at $70^{\circ} \mathrm{C}$ and maximum $\mathrm{V}_{\mathrm{mpp}}$ at $15^{\circ} \mathrm{C}$ under $1000 \mathrm{~W} / \mathrm{m}^{2}$ irradiance). The open circuit voltage ( $V_{\text {oc }}$ ) was designed as $600 \mathrm{~V}$ maximum (under $-10^{\circ} \mathrm{C}$ and $1000 \mathrm{~W} / \mathrm{m}^{2}$ irradiance). The performance in terms of maximum peak power capacity of $4.22 \mathrm{~kW}$ was defined (with a tolerance up to $5.7 \mathrm{~kW})$. System simulations were investigated for Top facing ( $0^{\circ}$ inclination angle) and $90^{\circ}$ inclination for the following orientation / azimuth angles - South $\left(180^{\circ}\right)$, East $\left(90^{\circ}\right)$, West $\left(270^{\circ}\right)$, and North $\left(0^{\circ}\right)$, facing facades. South-facing rooftop arrays at $37^{\circ}$ inclination (the optimal angle for this latitude) were also simulated with and without battery storage to compare the optimum positioning of modules in a BIPV array.

The software flags an error when modelling the North facing façade because the performance ratio (PR) drops to $45 \%$ and the sizing factor drops below 105.5 . The sizing factor (SF), performance ratio (PR) and Specific Annual Yield (SAY) is defined in equations 5,6 and 7;

Sizing factor $=\frac{P V \text { generator power }(k W)}{\text { Inverter } A C \text { power rating }(k V A)}$ 
To compute performance of a BIPV arrays, four 4.2kWp OPV systems scenarios have been investigated for (1) the highest annual energy generation, (2) architecturally evenly-spaced around the building (avoiding North façade), (3) grid-balancing and (4) East-West split.

\section{Results}

\subsection{Diurnal performance}

The outdoor monitoring setup was installed as discussed in section 2.2 for a period of 8 months from Dec 2015 - July 2016. Throughout the entire period of this investigation the incident irradiance and weather conditions were monitored simultaneously with the OPV modules. To evaluate the diurnal performance four contrasting days were selected; a sunny and cloudy day in winter and summer periods. Sunny conditions were defined with a daily insolation $\geq 80 \%$ nominal maximum value, and cloudy days when the daily insolation was $<40 \%$ of the nominal maximum value for that particular month based upon historic metrological data.

When considering sunny days in figures $2 \mathrm{a}$ ) and c), it is clear that orientation has an impact on the module performance and also which module performs best at different periods of the day. During the winter time when the sun's maximum elevation only reaches $16.35^{\circ}$ so the south facing modules outperform all others. This trend continues until the end of February when the maximum solar elevation reaches $28.8^{\circ}$. After this date, the zenith angle between sunrise and sunset increases resulting in the horizontally positioned module having the greatest diurnal power output in May, see figure 3 (c). Due to the high solar elevation of $56.2^{\circ}$ in May and also low zenith of $33.7^{\circ}$ the horizontal modules substantially outperform the South facing ones.

The performance of East and West facing modules (which are rarely reported for OPV performance) show a differing impact on power generation depending on the season. In summer months, they can significantly impact on power generation in the early morning and late evening, respectively. These modules could contribute to the grid-balancing of PV power generation during peak hours. Recently, there has been a growing demand from PV installers to deploy East-West facing modules in c-Si solar farms; the first such plant was commission in September 2013 [29] and 
such a configuration could be readily transferred for building integration to improve distribution of energy supply within buildings. However, in winter time, the east/west modules do not have a significant impact, due to the increased distance of the Earth from the Sun producing much lower irradiance values in morning and evenings, in addition to the shorter daylight hours. Therefore, the power generation in winter time is only marginally balanced by the East-West modules in mornings and evenings.

As to be expected, the North facing module exhibits the worst performance out of all modules on sunny days. The north facing module does not receive any direct irradation as it never faces the sun during its diurnal solar path It will therefore only be irradiated by diffuse and albedo irradiation. Diffuse light is much greater on cloudy days than sunny days [29-30], so the module performs better on cloudy days than it does on sunny ones. It is for this reason as well that the relative of performance of the north facing module, in comparison to all other modules, is better on cloudy days than on sunny ones. When considering the days of high cloudiness [figures $3 \mathrm{~b}$ ) and d)], the top facing modules appear to always outperform modules positioned side-facing. This has been previously reported in $\mathrm{c}-\mathrm{Si}^{17}$ modules and is explained by the distribution of scattered radiation in the sky. When there is low cloud coverage the sun irradiation reaches the surface of the earth at an optimum of $90^{\circ}$ angle, but when sky is covered uniformly with clouds the diffuse radiation is considered to be equally distributed. Under these conditions, it is clear that the horizontally positioned OPV modules generate the most power. It is noticeable that during such days of high cloud cover, all other modules have almost identical level of performances, including the North facing modules, indicating some potential for OPVs on a North-facing wall.

\subsection{Monthly yield}

The monthly energy yield per $\mathrm{cm}^{2}$ was calculated from equation 4 and plotted in figure 4 , where it is evident that the best performing modules is a function of a calendar month. The study was carried out for 8 months. By month 8 , the north and west facing modules had degraded by $10 \%$ of their initial PCE value and the test was halted as it was no longer possible to compare fairly the relative energy yields of the different modules. During the winter period (December - February), the South facing modules contributes the greatest portion to the electricity generation. This is due to the lower solar elevation of between $16.35^{\circ}$ and $28.8^{\circ}$ at this latitude and thus is better positioned for sunlight absorption. In fact, South facing modules generate a factor of two more energy during these months than the next best performing module (the horizontally positioned module). North, West and East facing modules generate similar levels of power, although the East facing modules are affected by shading losses due to nearby Snowdonia mountain range which impacts the Winter data collection. 
From March onwards, the horizontally positioned module has the greatest monthly energy yield due to the higher solar elevation. By June, this is approximately a factor of two greater than the South facing module. From May, the East and West facing modules generate greater output power than the South facing module. This trend can be explained by the longer days and lower proportion of diffused light in summer. The latter also explains the significant relative drop in yield from the North-facing module. When considering East and West facing modules and their greater output over the South-facing modules in summer time, the attributed cause is related to the critical angle of incidence of $45^{\circ}$. By midday (which is $1: 15 \mathrm{pm}$ in June), the solar elevation has already reached $58.8^{\circ}$ and therefore the South-facing module experiences reduced light in-coupling due to reflection losses. In contrast, the East and West facing modules, experience their peak times and solar elevation respectively at 9:15am for East with $35.30^{\circ}$ and 5:30pm for West with $32.90^{\circ}$ where reflection losses are lower. Interestingly, the East facing module is always moderately better performing than the West facing one possibly due to morning sun glare (albedo) from the reflected light from the Menai Strait (nearby sea) located 500m from School of Electronic Engineering where the test rig is positioned.

\subsection{Performance during peak hours}

The importance of balancing energy generation is of growing importance for renewable energy generators. Peak demand in the UK occurs from 16:30-19:30pm and during this time retail electricity prices are elevated for many consumers [18]. The peak hour power generation by buildings with multi-sided PV installations could act as a strategy to balance peak demands. Considering figure 5, West-facing modules have the greatest capacity to contribute to power generation during peak hours. The West-facing module outperforms all other modules during peak times, except in July (when there was an abnormally large number of diffuse days). The horizontally positioned modules are considered as second best for peak-hour power generation. However, it is important to note that in winter months (Dec-Feb), small amounts of power are generated by any modules, so this strategy is only effective during summer months.

\subsection{Performance during different climatic conditions}

Based upon the data in section 3.1, it is clear relative module performance is affected by climatic conditions. Figure 6 shows the monthly yield from all modules under specific weather conditions for January and June. To view the climatic effect, the power generation was divided into sunny, intermittent and cloudy/diffuse conditions according to the solar insolation levels relative to the nominal maximum daily irradiation [5]. Sunny conditions were defined with a daily insolation $\geq 80 \%$ nominal maximum value, intermittent $\geq 40 \% \&<80 \%$ and cloudy $<40 \%$. This data is particularly important for countries with temperate climatic conditions, such as North and central Europe and 
Northern USA, where the majority of days are categorised by their insolation levels as being within the "intermittent" category.

In the winter, the South facing modules are best performing except in cloudy conditions where the horizontally positioned modules are superior, due to increased diffuse irradiation as discussed in section 3.1. During sunny days, it is clear that the North, West and East facing are all poor performing due to the low solar elevation. However, under diffuse conditions, the output is only marginally worse than a South facing module.

However, in June, the horizontally positioned module performs best in all conditions. In sunny climates, the East facing modules appear the second best, which can be equated to the summer trend in the UK of higher direct radiation in morning and greater cloudiness in the afternoon ${ }^{4}$. In cloudy conditions, all modules, including the North appear to perform similarly.

\subsection{System level simulation}

Initially, system simulations were investigated for South-facing and optimally tilted at $37^{\circ}$ (to benchmark the BIPV performance), horizontal ( $0^{\circ}$ inclination angle), and $90^{\circ}$ inclination angle for the following orientation / azimuth angles - South $\left(180^{\circ}\right)$, East $\left(90^{\circ}\right)$, West $\left(270^{\circ}\right)$, and North $\left(0^{\circ}\right)$, facing facades. Table 2 summarises the simulated performance of OPV module arrays on different sides of a building. As expected, the South facing rooftop with $37^{\circ}$ tilt system provided the optimal energy generation throughout the year $(3,971 \mathrm{kWh})$, reaching a maximum of $567 \mathrm{kWh}$ in May. The rooftop array exhibited $\sim 20 \%$ lower estimated energy production $(3,222 \mathrm{kWh})$ by reducing the inclination angle from 37 to $0^{\circ}$. The East facing façade estimated generation (1,858 kWh) had a similar (but much lower) generation profile, reaching a maximum of $323 \mathrm{kWh}$ in May. The West facing façade estimated generation $(1,903 \mathrm{kWh})$ had a much broader generation profile, with maximum energy generation of 280-295 kWh between May and July. The South facing façade (total annual energy generation 2,640 kWh) reaches peak generation in April, with fairly consistent generation from June to October of 234-243 kWh. As predicted, the North facing façade produced the least energy through the year (687 kWh), with a peak generation in June of $144 \mathrm{kWh}$. The Specific Annual Yield is compared to the experimental data obtained in section 3 and close correlation is observed between the datasets, demonstrating the validity of the simulations. The monthly energy generated (kWh) and fed into the grid for each PV façade orientation and inclination angle is given in figure 8.

As a further investigation, the potential of OPVs to sustain an office building was considered. Typical load profiles for a small commercial office, with business hours 08:00 to 18:00 and $1000 \mathrm{kWh}$ annual energy consumption (peak load 500W), were imported into PVSOL. The $4.22 \mathrm{kWp}$ OPV system 
was modelled with a South facing orientation and $37^{\circ}$ inclination angle. A BAE Sun depot 24-280 $(4 \mathrm{~kW})$ battery with an output of $4 \mathrm{~kW}$ was selected, with a maximum charging/discharging power of $4 \mathrm{~kW}$ over 30 minutes. The minimum state of charge (SOC) was selected as $10 \%$ with a maximum of $90 \%$. The DC battery system voltage was chosen as $24 \mathrm{~V}$ with 12 batteries per string. The battery capacity (C10) selected was $860 \mathrm{Ah}$, usable battery energy $16.5 \mathrm{kWh}$. The system model indicates $3971 \mathrm{kWh}$ of energy generation with $3327 \mathrm{kWh}$ grid feed-in. The PV system could supply daily energy demand for spring, summer and autumn when irradiance (horizontal plane) exceeds $25 \mathrm{kWh} / \mathrm{m}^{2}$. Energy consumption from the grid was calculated as $73 \mathrm{kWh}$, with annual grid feed-in of 2,812kWh and a solar fraction of $92.7 \%$. Due to the low irradiance levels of 15.9 and $21.6 \mathrm{kWh} / \mathrm{m}^{2}$ in December and January, winter power demand is predominantly grid-supplied. The grid energy consumed throughout the year varied from 8 to $20 \mathrm{kWh}$. The energy fed to the grid vs energy consumption is presented in figure 9.

Finally, the configuration of potential BIPV arrays were considered. Four $4.2 \mathrm{kWp}$ peak capacity OPV system scenarios were modelled to give the highest annual energy generation with a South-facing rooftop array at $37^{\circ}$ inclination (\#1) and an evenly-spaced OPV system around the building with $4 \times 1.05 \mathrm{kWp}$ systems incorporating South-facing $37^{\circ}$ and South, West and East facades (\#2). A grid-balancing case with $2.11 \mathrm{kWp}$ on South facing rooftop at $37^{\circ}$ and $0.7 \mathrm{kWp}$ on East, West and South-facing facades (\#3). Finally, an East-West OPV solution was modelled as two $2.11 \mathrm{kWp}$ systems (\#4) for building rooftops deemed unsuitable in terms of area, weight-bearing capacity or inclination angle (e.g. flats). The data for all of the scenarios is presented in Table 3. The simulation for scenario 1 estimates 3,971 kWh annual energy generation with a high SAY of $941 \mathrm{kWh} / \mathrm{kWp}$ and PR 78\%. Scenario 2 estimates a combined annual energy generation of 2,675 kWh with SAY of 465 (E), $475(\mathrm{~W}), 644$ (S facade) and 964 (S $\left.37^{\circ}\right) \mathrm{kWh} / \mathrm{kWp}$ and PR ranging from 70 to $79 \%$. Grid-balancing scenario 3 estimates 2,759 kWh annual energy generation with SAY of 456 (E), 467 (W), 627 (S façade) and 794 (S $\left.37^{\circ}\right)$, PR ranging from 66 to $70 \%$. East-West scenario 4 predicts 1,970 kWh annual energy generation with SAY of 462 (E) and 472 (W) with PR of 70\% for both. The energy generated and fed to the grid for each scenario is presented as Figures 10 (a) to (d).

\section{Conclusion}

The outdoor dependence of module orientation and diurnal climate conditions on the performance of OPVs configured for a BIPV array has been analysed. The performance was examined over the course of 8 consecutive months. We showed how significant module orientation is to energy yield across diurnal and seasonal change. The top-facing module clearly has the best energy yield for BIPV modules. However, west facing modules can significantly contribute to power generation during 
peak power periods, which is imperative for balancing energy demand. System simulations were developed based upon the results achieved and show reasonable overlap to experimental data. Simulation of PV array performance was compared to demand profiles of commercial and residential buildings and illustrate that OPV arrays show strong potential to be used with excess energy generation for 8 months of the year for a $4.22 \mathrm{kWp}$ OPV system.

\section{Acknowledgements}

Vasil Stoichkov would like to thank the Sêr Cymru National Research Network for funding of his PhD studies. The work was supported by the Solar Photovoltaic Academic Research Consortium II (SPARC II) project, gratefully funded by WEFO. We also acknowledge that Dr Sjoerd Veenstra of the ECN had started work studying OPV performance on different sides of a building prototype prior to the initiation of the work reported here.

\section{References}

[1] L. Dou, J. You, Z. Hong, Z. Xu, G. Li, R.A. Street, Y. Yang, 25th anniversary article: A decade of organic/polymeric photovoltaic research, Adv. Mater. 25 (2013) 6642-6671. doi:10.1002/adma.201302563.

[2] J. You, L. Dou, K. Yoshimura, T. Kato, K. Ohya, T. Moriarty, K. Emery, C.C. Chen, J. Gao, G. Li, Y. Yang, A polymer tandem solar cell with $10.6 \%$ power conversion efficiency, Nat. Commun. 4 (2013) 1446. doi:10.1038/ncomms2411.

[3] H. Zhou, Y. Zhang, C.K. Mai, S.D. Collins, G.C. Bazan, T.Q. Nguyen, A.J. Heeger, Polymer homotandem solar cells with best efficiency of 11.3\%, Adv. Mater. 27 (2015) 1767-1773. doi:10.1002/adma.201404220.

[4] N. Bristow, J. Kettle, Outdoor performance of organic photovoltaics: Diurnal analysis, dependence on temperature, irradiance, and degradation, J. Renew. Sustain. Energy. 7 (2015). doi:10.1063/1.4906915.

[5] J. Kettle, N. Bristow, T.K.N. Sweet, N. Jenkins, G. a. dos Reis Benatto, M. Jørgensen, F.C. Krebs, Three dimensional corrugated organic photovoltaics for building integration; improving the efficiency, oblique angle and diffuse performance of solar cells, Energy Environ. Sci. 8 (2015) 3266-3273. doi:10.1039/C5EE02162F.

[6] S. Lizin, S. Van Passel, E. De Schepper, L. Vranken, The future of organic photovoltaic solar cells as a direct power source for consumer electronics, Sol. Energy Mater. Sol. Cells. 103 (2012) 1-10. doi:10.1016/j.solmat.2012.04.001.

[7] P. Heinstein, C. Ballif, L.E. Perret-Aebi, Building integrated photovoltaics (BIPV): Review, potentials, barriers and myths, Green. 3 (2013) 125-156. doi:10.1515/green-2013-0020.

[8] S. Berny, N. Blouin, A. Distler, H.J. Egelhaaf, M. Krompiec, A. Lohr, O.R. Lozman, G.E. Morse, L. Nanson, A. Pron, T. Sauermann, N. Seidler, S. Tierney, P. Tiwana, M. Wagner, H. Wilson, Solar trees: First large-scale demonstration of fully solution coated, semitransparent, flexible organic photovoltaic modules, Adv. Sci. 3 (2015) 1-7. doi:10.1002/advs.201500342.

[9] S.B. Darling, F. You, The case for organic photovoltaics, RSC Adv. 3 (2013) 17633-17648. doi:10.1039/c3ra42989j.

[10] D. Angmo, F.C. Krebs, Over 2Years of Outdoor Operational and Storage Stability of ITO-Free, 
Fully Roll-to-Roll Fabricated Polymer Solar Cell Modules, Energy Technol. 3 (2015) 774-783. doi:10.1002/ente.201500086.

[11] J.A. Hauch, P. Schilinsky, S.A. Choulis, R. Childers, M. Biele, C.J. Brabec, Flexible organic P3HT:PCBM bulk-heterojunction modules with more than 1 year outdoor lifetime, Sol. Energy Mater. Sol. Cells. 92 (2008) 727-731. doi:10.1016/j.solmat.2008.01.004.

[12] J. Robertson, High density plasma enhanced chemical vapor deposition of optical thin films, Eur. Phys. J. Appl. Phys. 28 (2004) 265-291. doi:10.1051/epjap.

[13] M.O. Reese, S.A. Gevorgyan, M. Jorgensen, E. Bundgaard, S.R. Kurtz, D.S. Ginley, D.C. Olson, M.T. Lloyd, P. Morvillo, E.A. Katz, A. Elschner, O. Haillant, T.R. Currier, V. Shrotriya, M. Hermenau, M. Riede, K.R. Kirov, G. Trimmel, T. Rath, O. Inganas, F. Zhang, M. Andersson, K. Tvingstedt, M. Lira-Cantu, D. Laird, C. McGuiness, S. Gowrisanker, M. Pannone, M. Xiao, J. Hauch, R. Steim, D.M. Delongchamp, R. Roesch, H. Hoppe, N. Espinosa, A. Urbina, G. YamanUzunoglu, J.B. Bonekamp, A.J.J.M. Van Breemen, C. Girotto, E. Voroshazi, F.C. Krebs, Consensus stability testing protocols for organic photovoltaic materials and devices, Sol. Energy Mater. Sol. Cells. 95 (2011) 1253-1267. doi:10.1016/j.solmat.2011.01.036.

[14] European Union, L 140, Off. J. Eur. Union. 52 (2009) 20. doi:10.3000/17252555.L_2009.140.eng.

[15] M.B. Schubert, J.H. Werner, Flexible solar cells for clothing, Mater. Today. 9 (2006) 42-50. doi:10.1016/S1369-7021(06)71542-5.

[16] L. Hughes, N. Bristow, T. Korochkina, P. Sanchez, D. Gomez, J Kettle, D.T. Gethin, Assessing the potential of steel as a substrate for building integrated photovoltaic applications. Applied energy, 229, 209-223. (2018)

[17] Heliatek, The world's largest BiOPV installation completed in France using Heliatek's Solar Film Solution, HeliaSol ${ }^{\circledR}$, (2017) 5-7.

http://www.heliatek.com/de/presse/pressemitteilungen/details/weltweit-groesste-biopvinstallation-mit-heliateks-solarfolienloesung-heliasol-in-frankreich.

[18] BELECTRIC, The world's first grid-connected OPV system has been running reliably since 2012, (2016) 3-6.

[19] H.P. Kim, H.J. Lee, A.R. Bin Mohd Yusoff, J. Jang, Semi-transparent organic inverted photovoltaic cells with solution processed top electrode, Sol. Energy Mater. Sol. Cells. 108 (2013) 38-43. doi:10.1016/j.solmat.2012.09.002.

[20] K.-S. Chen, J.-F. Salinas, H.-L. Yip, L. Huo, J. Hou, A.K.-Y. Jen, Semi-transparent polymer solar cells with $6 \%$ PCE, $25 \%$ average visible transmittance and a color rendering index close to 100 for power generating window applications, Energy Environ. Sci. 5 (2012) 9551. doi:10.1039/c2ee22623e.

[21] R.R. Lunt, V. Bulovic, Transparent, near-infrared organic photovoltaic solar cells for window and energy-scavenging applications, Appl. Phys. Lett. 98 (2011). doi:10.1063/1.3567516.

[22] Z. Ding, V. Stoichkov, M. Horie, E. Brousseau, J. Kettle Spray coated silver nanowires as transparent electrodes in OPVs for Building Integrated Photovoltaics applications, Sol. Energy Mater. Sol. Cells. 157 (2016) 305-311. doi:10.1016/j.solmat.2016.05.053.

[23] Y. Galagan, D.J.D. Moet, D.C. Hermes, P.W.M. Blom, R. Andriessen, Large area ITO-free organic solar cells on steel substrate, Org. Electron. Physics, Mater. Appl. 13 (2012) 33103314. doi:10.1016/j.orgel.2012.09.039.

[24] V. Kumar, H. Wang, Selection of metal substrates for completely solution-processed inverted organic photovoltaic devices, Sol. Energy Mater. Sol. Cells. 113 (2013) 179-185. doi:10.1016/j.solmat.2013.02.010.

[25] J. Hu, W. Chen, Y. Yin, Y. Li, D. Yang, H. Wang, X. Zhang, Electrical-thermal-mechanical 
properties of multifunctional OPV-ETFE foils for large-span transparent membrane buildings, Polym. Test. 66 (2018) 394-402. doi:10.1016/j.polymertesting.2018.01.036.

[26] A. Menéndez, A. Martínez, A. Santos, B. Ruiz, K. Moritz, I. Klein, J. Díaz, A.R. Lagunas, T. Sauermann, D. Gómez, A multifunctional ETFE module for sustainable façade lighting: Design, manufacturing and monitoring, Energy Build. 161 (2018) 10-21. doi:10.1016/j.enbuild.2017.12.023.

[27] J. Kettle, N. Bristow, D.T. Gethin, Z. Tehrani, O. Moudam, B. Li, E.A. Katz, G.A. dos Reis Benatto, F.C. Krebs, Printable luminescent down shifter for enhancing efficiency and stability of organic photovoltaics, Sol. Energy Mater. Sol. Cells. 144 (2016) 481-487. doi:10.1016/j.solmat.2015.09.037.

[28] D. Kaduwal, B. Zimmermann, U. Würfel, ITO-free laminated concept for flexible organic solar cells, Sol. Energy Mater. Sol. Cells. 120 (2014) 449-453. doi:10.1016/j.solmat.2013.09.024.

[29] M. Hartner, A. Ortner, A. Hiesl, R. Haas, East to west - The optimal tilt angle and orientation of photovoltaic panels from an electricity system perspective, Appl. Energy. 160 (2015) 94107. doi:10.1016/j.apenergy.2015.08.097.

[30] M. Mehrtash, G. Quesada, Y. Dutil, D. Rousse, Performance Evaluation of Sun Tracking Photovoltaic Systems in Canada, 20th Annu. Int. Confernece Mech. Eng. (2012) 18-21. http://www.t3e.info/pdf/Publications/2012-ISME- Performance Evaluation of Sun Tracking Photovoltaic Systems in Canada.pdf.

[31] A.J. Roscoe, G.W. Ault, Supporting high penetrations of renewable generation via implementation of real-time electricity pricing and demand response, IET Renew. Power Gener. (2010) 369-382. http://dx.doi.org/10.1049/iet-rpg.2009.0212.

[32] Teijin DuPont PEN, (n.d.). http://www.teijindupontfilms.jp/english/product/pen_teo.html. 
Table 1-OPV module input parameters for systems level simulations.

\begin{tabular}{|c|c|c|c|c|}
\hline Parameter & Laborator & odule* & Simulatio & dule \\
\hline Test conditions & Standard & Part-load & Standard & Part-load \\
\hline Irradiance $\left(\mathrm{W} / \mathrm{m}^{2}\right)$ & 1000 & 299 & 1000 & 300 \\
\hline Temperature $\left({ }^{\circ} \mathrm{C}\right)$ & 25 & 11.9 & 25 & 25 \\
\hline Vmpp (V) & 3.4 & 2.9 & 3.4 & 2.9 \\
\hline Impp (A) & 0.033 & 0.0095 & 3.30 & 0.95 \\
\hline $\operatorname{Voc}(V)$ & 5.2 & 4.32 & 5.2 & 4.32 \\
\hline $\operatorname{Isc}(A)$ & 0.05 & 0.0163 & 5.0 & 1.60 \\
\hline Poutput (W) & 0.11 & 0.027 & 11.0 & 2.8 \\
\hline Fill Factor (\%) & 40.54 & 40.03 & 40.54 & 40.03 \\
\hline Area $\left(\mathrm{m}^{2}\right)$ & 0.0064 & 0.0064 & 0.64 & 0.64 \\
\hline Efficiency (\%) & 1.7 & 1.4 & 1.7 & 1.4 \\
\hline
\end{tabular}

*Outdoor data was collected at $950 \mathrm{~W} / \mathrm{m}^{2}$ and $299 \mathrm{~W} / \mathrm{m}^{2}$ for standard and part-load conditions. This data was scaled to obtain $1000 \mathrm{~W} / \mathrm{m}^{2}$ and $300 \mathrm{~W} / \mathrm{m}^{2}$ for the system-level simulations.

Table 2 - Simulation data for Top, South, East, West and North-facing PV systems. Shown is a comparison with the experimental data in figure 4. Overall, there is a reasonable overlap between simulation and experimental data, but the simulation overestimates the energy generation from the north and east facing modules.

\begin{tabular}{|l|l|l|l|l|l|l|l|}
\hline Orientation & $\begin{array}{l}\text { Azimuth } \\
\text { angle } \mathbf{(}^{\circ} \text { ) }\end{array}$ & $\begin{array}{l}\text { Tilt } \\
\text { angle } \\
\left(\mathbf{(}^{\circ}\right.\end{array}$ & $\begin{array}{l}\text { Annual } \\
\text { Energy } \\
\mathbf{( k W h )}\end{array}$ & $\begin{array}{l}\text { Performance } \\
\text { ratio (\%) }\end{array}$ & $\begin{array}{l}\text { Specific } \\
\text { Annual } \\
\text { Yield } \\
\text { (kWh/kWp) }\end{array}$ & $\begin{array}{l}\text { \% of } \\
\text { Specific } \\
\text { Annual } \\
\text { Yield } \\
\text { (simulated) }\end{array}$ & $\begin{array}{l}\text { \% of Specific } \\
\text { Annual Yield } \\
\text { (Experimental) }\end{array}$ \\
\hline Rooftop & 180 & 0 & 3222 & 73.5 & 763.4 & 31.2 & 33.4 \\
\hline South & 180 & 90 & 2640 & 71.6 & 625.61 & 25.6 & 26.3 \\
\hline South & 180 & 37 & 3971 & 77.7 & 941.1 & n/a & n/a \\
\hline East & 90 & 90 & 1858 & 66.8 & 440.21 & 18.0 & 13.4 \\
\hline West & 270 & 90 & 1903 & 67.0 & 450.19 & 18.4 & 18.2 \\
\hline North & 0 & 90 & 687 & 45.2 & 162.84 & 16.2 & 8.68 \\
\hline
\end{tabular}

Table 3 - Systems simulation design for scenarios 1 (highest energy output), 2 (evenly-spaced architectural design), 3 (grid balancing) and 4 (East-West, no suitable rooftop).

\begin{tabular}{|c|c|c|c|c|c|c|c|}
\hline Scenario & $\begin{array}{l}\text { South } \\
37^{\circ}\end{array}$ & $\begin{array}{l}\text { East } \\
90^{\circ}\end{array}$ & $\begin{array}{l}\text { West } \\
90^{\circ}\end{array}$ & $\begin{array}{l}\text { South } \\
90^{\circ}\end{array}$ & Total & $\begin{array}{l}\text { Total annual } \\
\text { energy } \\
\text { generation }\end{array}$ & $\begin{array}{l}\text { Energy yield during peak } \\
\text { hours (kWh) }\end{array}$ \\
\hline & \multicolumn{5}{|c|}{ Peak capacity (kWp) } & (kWh) & (kWh) \\
\hline 1 & 4.22 & 0 & 0 & 0 & 4.22 & 3971 & 258.06 \\
\hline 2 & 1.05 & 1.05 & 1.05 & 1.05 & 4.20 & 2675 & 286.44 \\
\hline 3 & 2.11 & 0.7 & 0.7 & 0.7 & 4.21 & 2759 & 227.09 \\
\hline 4 & 0 & 2.11 & 2.11 & 0 & 4.22 & 1970 & 371.03 \\
\hline
\end{tabular}




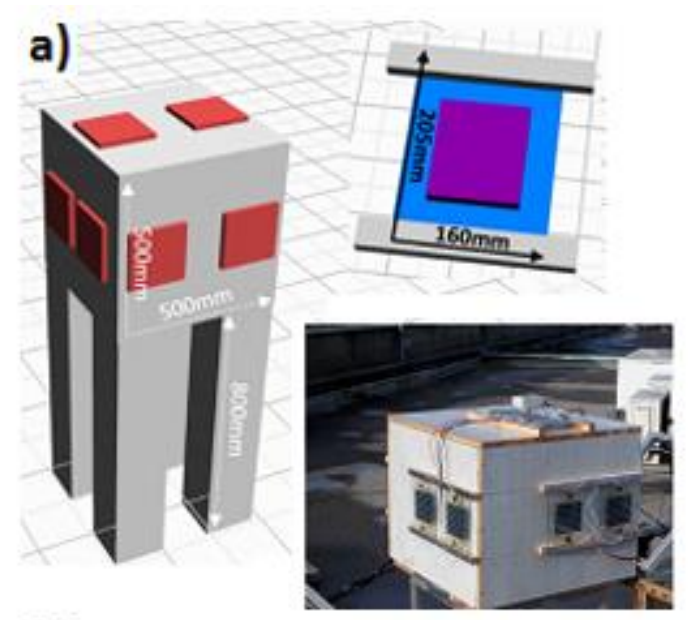

b)

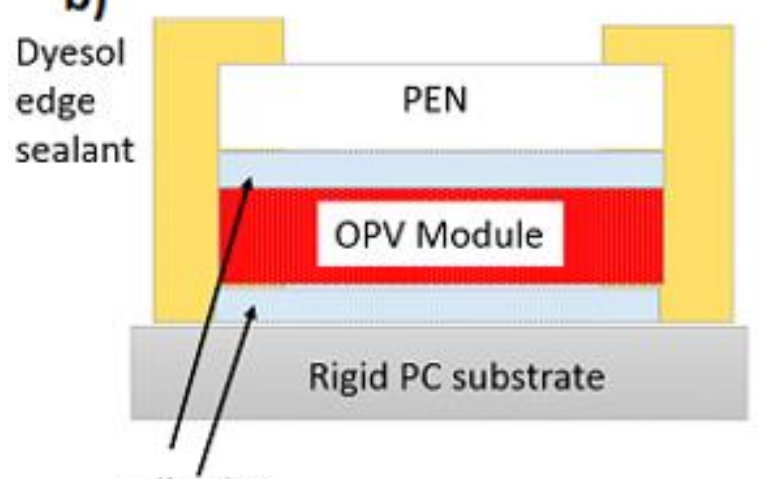

Adhesive

c)

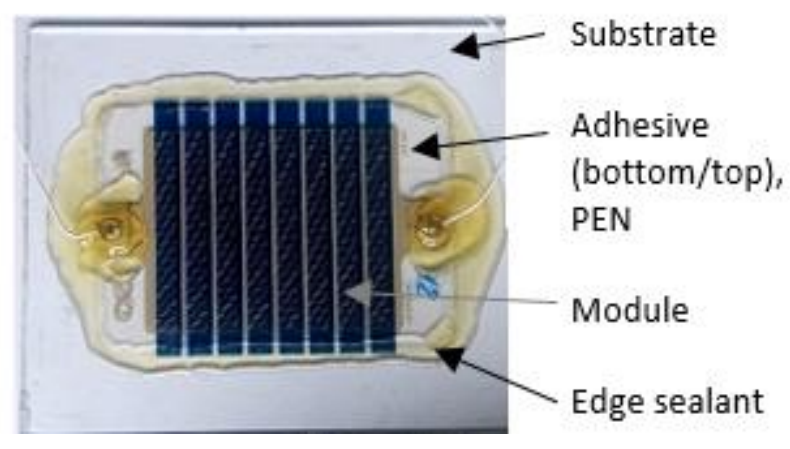

Figure 1 - (a) Design of cuboid structure deployed on the roof of the School of Electronic Engineering at Bangor University for outdoor measurements of BIPV modules, (b) cross sectional schematic of the encapsulated OPV from InfinityPV and (c) image of PV module prior to commencement of the experiment 

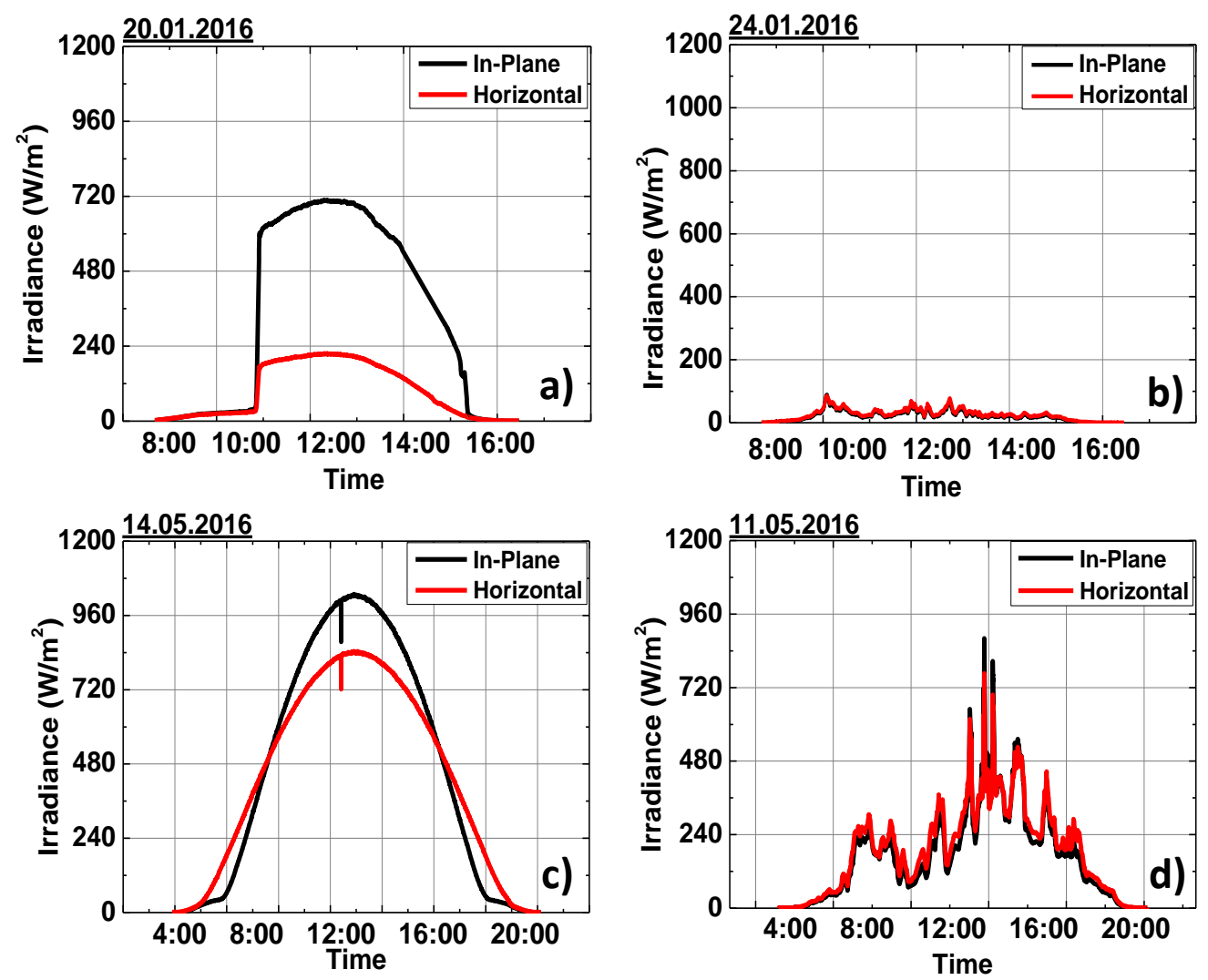

Figure 2 - Irradiance measurements recorded during a sunny (a) and cloudy day in winter (b) and sunny (c) and cloudy day in summer (d). 

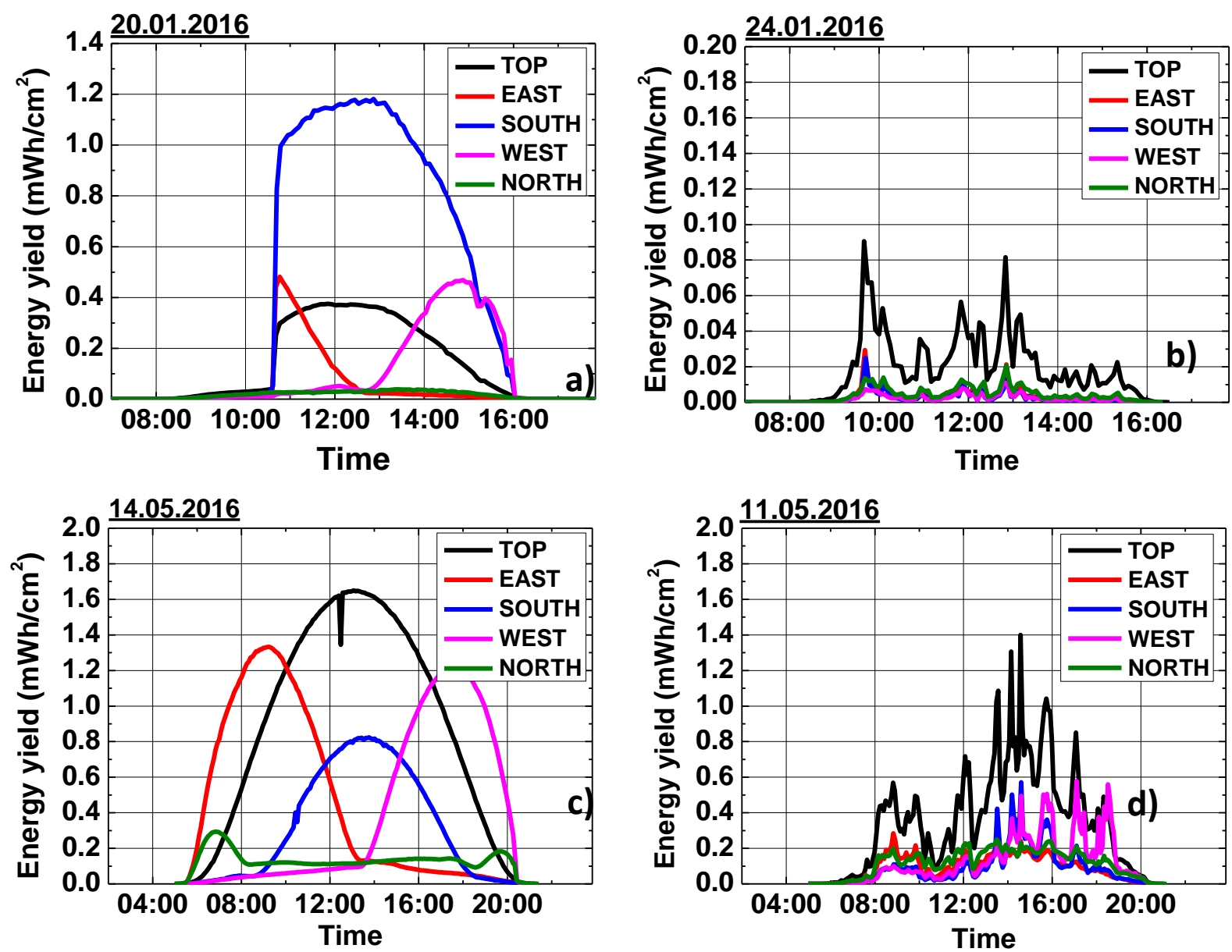

Figure 3-Diurnal performance of the OPV modules for a sunny (a) and cloudy day in winter (b) and sunny (c) and cloudy day in summer (d). 


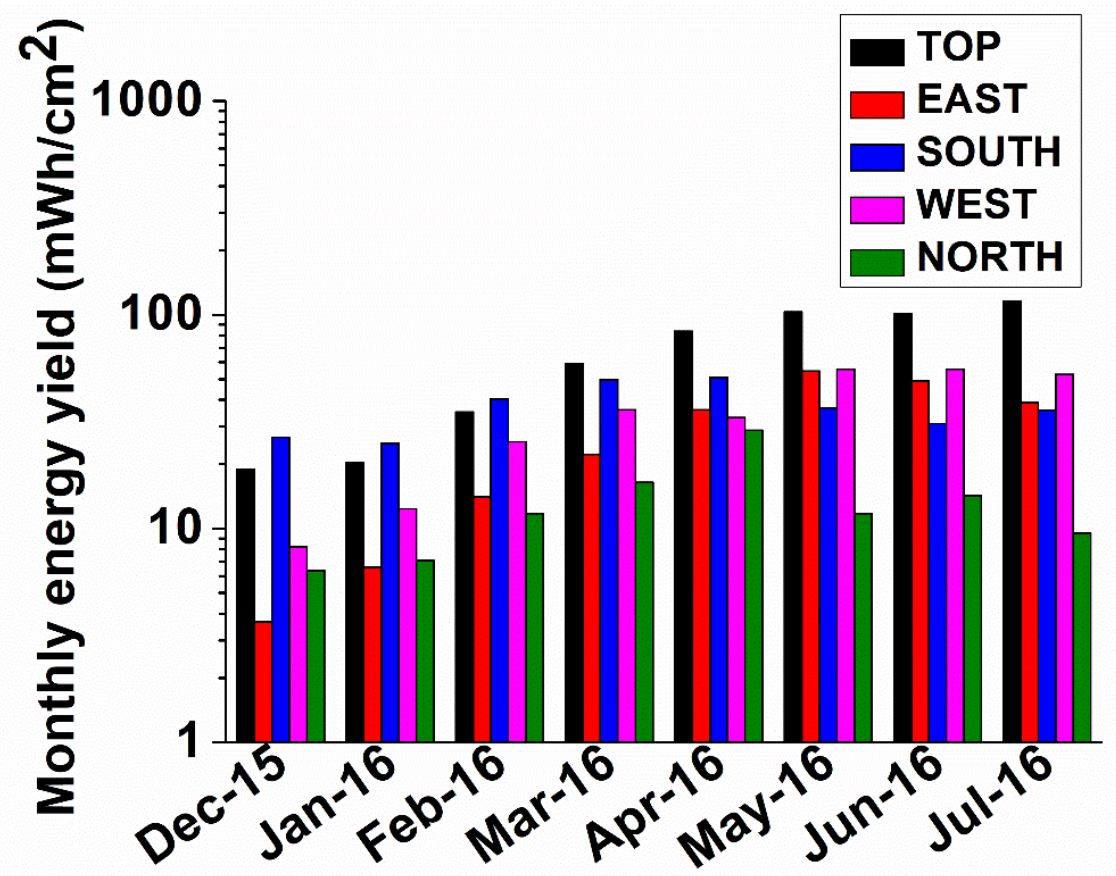

Figure 4-Graph of the monthly energy yield as a function of module position from December 2015 through to July 2016.

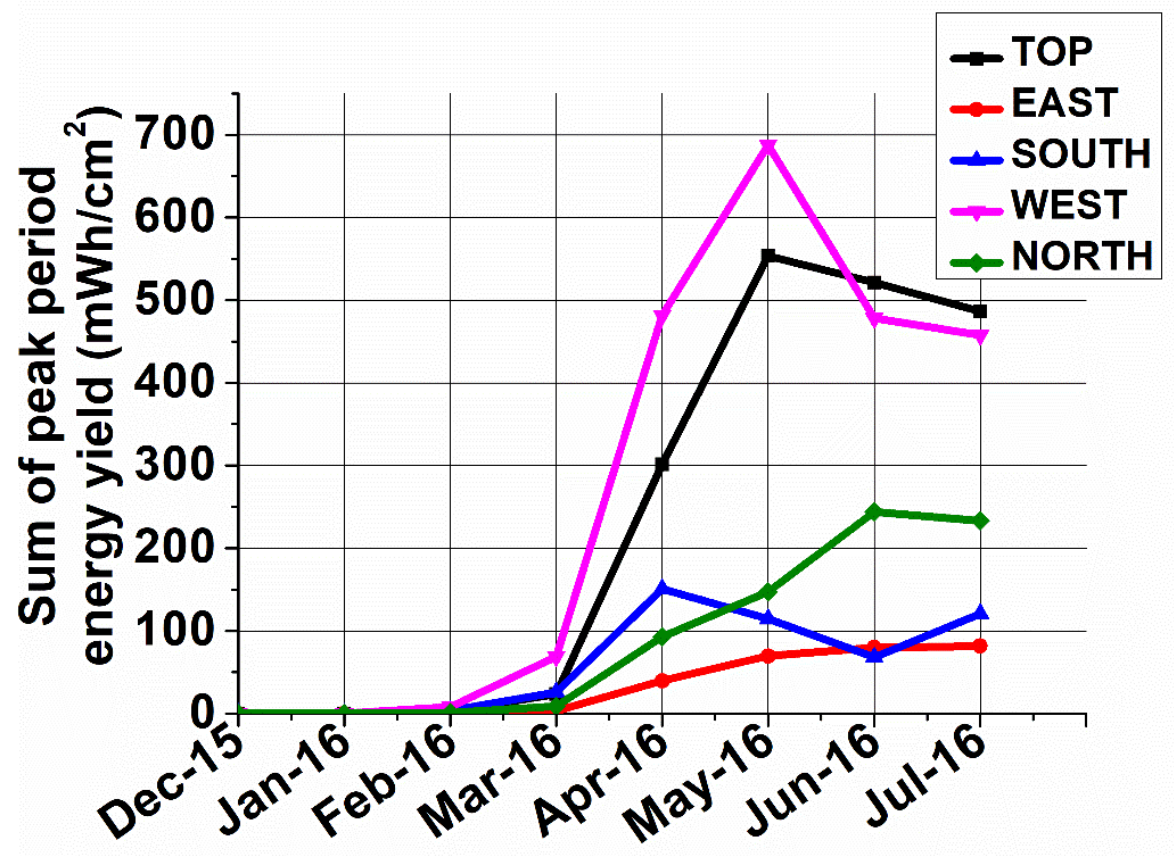

Figure 5 - Plot of peak energy generated as a function of month and position of module. No peakperiod power generation during winter months with gradual increase in mid-February to March followed by a sharp rise thereafter. 
(a)

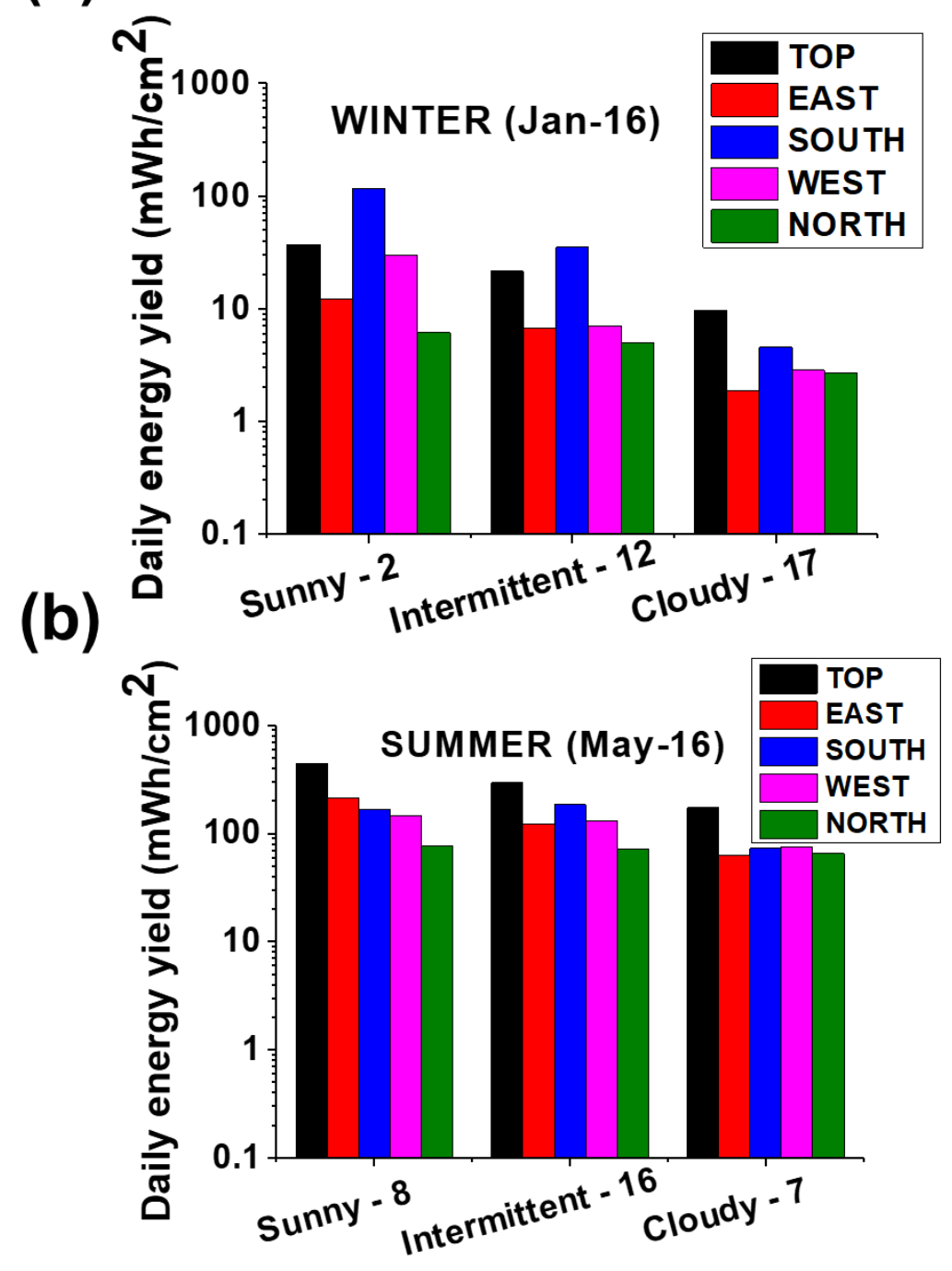

Figure 6-Energy yield $\left(\mathrm{mWh} / \mathrm{cm}^{2}\right)$ under three distinctive categories (sunny, intermittent, and cloudy) for a) winter and b) summer On the $x$-axis, the number of days in the month for each category is stated (e.g. Jan-16, 2 sunny days are present in the month). 

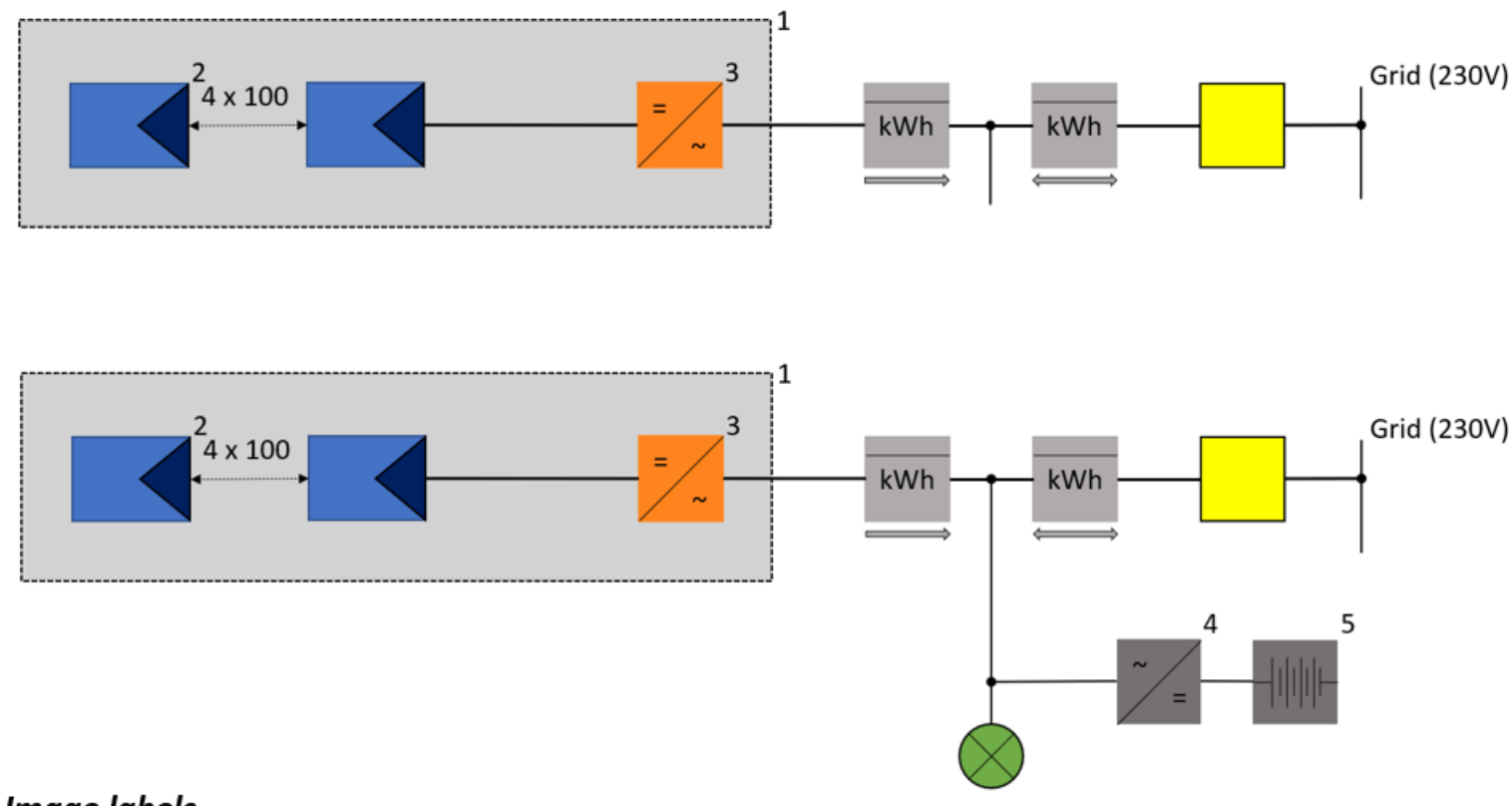

\section{Image labels}

1 - Array area $256 \mathrm{~m}^{2}$, South facing, $180^{\circ} .400$ OPV modules with peak production $4.22 \mathrm{kWp}$.

2 - OPV module - user defined, $10.54 \mathrm{~W}$ output.

3 - Sunny Boy inverter 400US, $240 \mathrm{~V}, 60 \mathrm{~Hz}$, SMA $4 \mathrm{~kW}$ max AC power $4 \mathrm{~kW}$.

4 - Battery inverter 2kW 24V.

5 - Battery 2V 1050Ah valve regulated.

Figure 7(a) OPV system simulation schematic diagram for full grid feed-in of power generate and (b) OPV system simulation schematic diagram with battery energy storage.

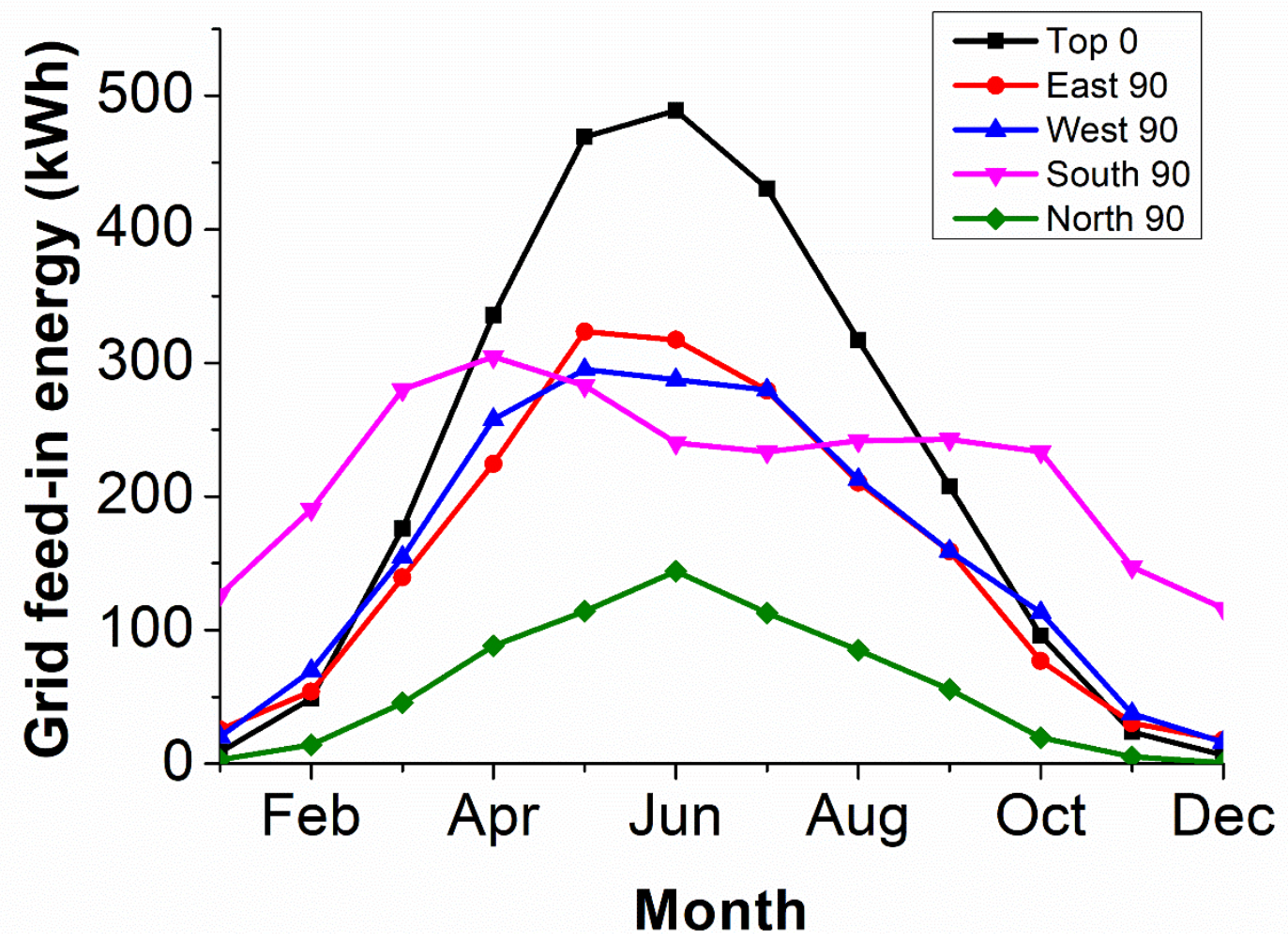

Figure 8 -Simulate grid energy feed-in ( $k W h$ ) vs month of the year by PV system orientation and inclination angle over the course of a full calendar year 


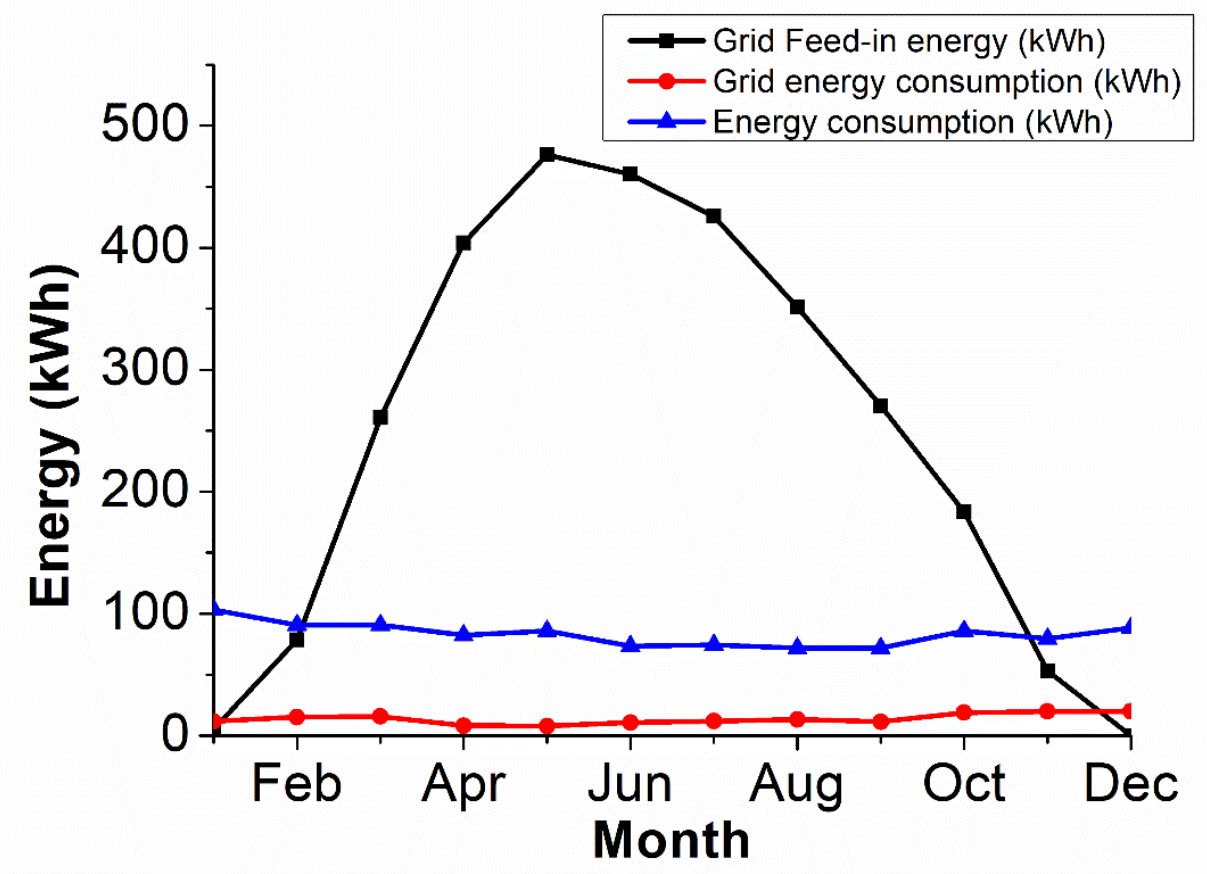

Figure 9 - Simulated energy yield showing grid feed-in vs grid and system energy consumption (kWh) over the course of a full calendar year

(a)

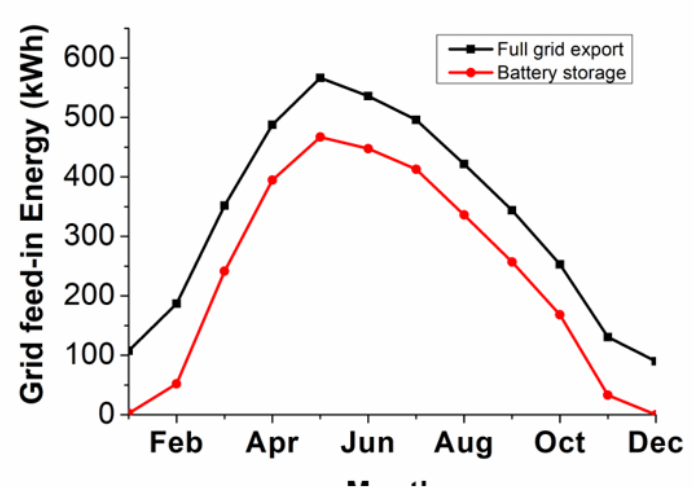

(c)

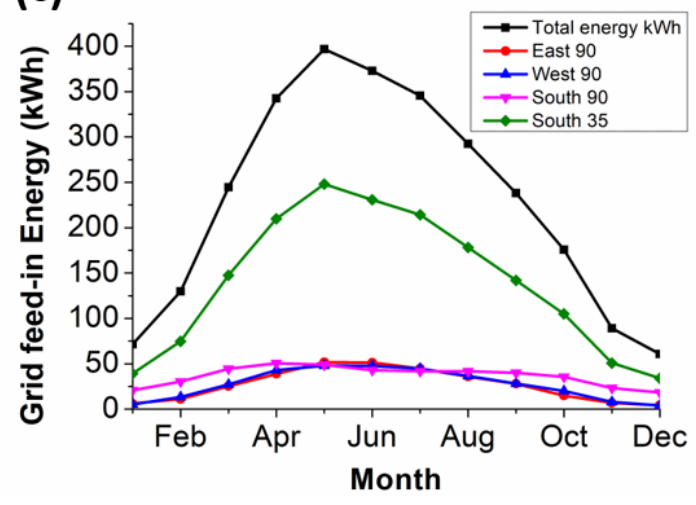

(b)

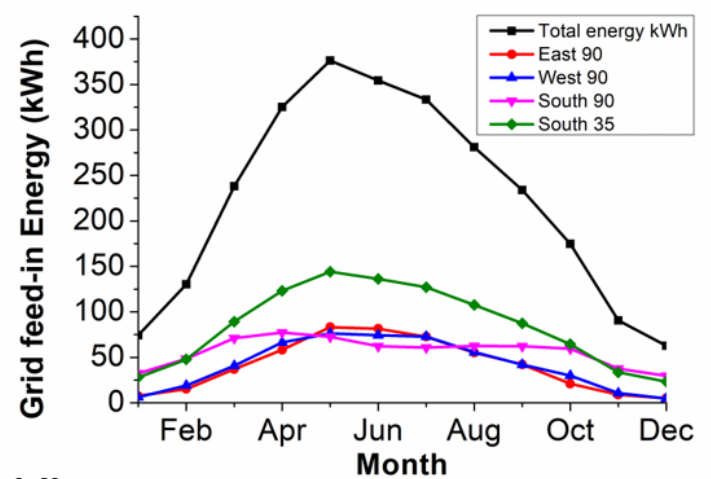

(d)

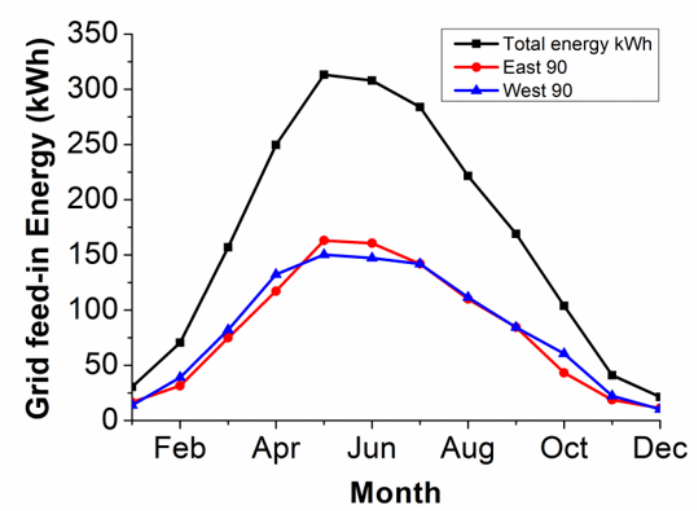

Figure 10 - Simulation of OPVs at system level including a $4.22 \mathrm{kWp}$ system (a) orientated at a South facing $37^{\circ}$ inclination (Scenario 1), (b) an evenly-distributed system with OPVs orientated to-, south- 
and east- and west facing (Scenario 2), (c) a 'balanced' systems with South $37^{\circ}(2.11 \mathrm{kWp}) \& 90^{\circ}$ $(0.7 \mathrm{kWp})$ East $90^{\circ}(0.7 \mathrm{kWp})$ and West $90^{\circ}(0.7 \mathrm{kWp})$ facing modules (Scenario 3) and finally, (d) an East-West OPV systems for buildings without suitable roof space (e.g. flats) with east- $90^{\circ}(2.11 \mathrm{kWp})$ and west $90^{\circ}$ facing modules $(2.11 \mathrm{kWp})$. 